This item was submitted to Loughborough's Research Repository by the author.

Items in Figshare are protected by copyright, with all rights reserved, unless otherwise indicated.

\title{
Between security and mobility: negotiating a hardening border regime in the Russian-Estonian borderland
}

PLEASE CITE THE PUBLISHED VERSION

http://dx.doi.org/10.1080/1369183X.2015.1015408

\section{PUBLISHER}

(c) Taylor \& Francis

\section{VERSION}

AM (Accepted Manuscript)

\section{PUBLISHER STATEMENT}

This work is made available according to the conditions of the Creative Commons Attribution-NonCommercialNoDerivatives 4.0 International (CC BY-NC-ND 4.0) licence. Full details of this licence are available at: https://creativecommons.org/licenses/by-nc-nd/4.0/

\section{LICENCE}

CC BY-NC-ND 4.0

\section{REPOSITORY RECORD}

Pfoser, Alena. 2015. "Between Security and Mobility: Negotiating a Hardening Border Regime in the Russianestonian Borderland”. Loughborough University. https://hdl.handle.net/2134/19104. 
Pre-print manuscript. For the final version see Journal of Ethnic and Migration Studies 41.10 (2015): 1684-1702

\title{
Between Security and Mobility: Negotiating a Hardening Border Regime in the Russian-Estonian Borderland
}

\author{
Alena Pfoser, Loughborough University, A.Pfoser2@lboro.ac.uk
}

\begin{abstract}
Since the end of the Cold War order post-Soviet borders have been characterised by geopolitical tensions and divergent imaginations of desirable political and spatial orders. Drawing upon ethnographic research in two border towns at the Russian-Estonian border, the article makes a case for a grounded examination of these border dynamics that takes into account how borders as sites of 'mobility and enclosure' are negotiated in everyday life and shaped by the differentiated incorporations of statecraft into people's lives. Depending on their historical memories, people interpret the border either as a barrier to previously free movement or as a security device and engage in correspondingly different relations to the state - privileging local concerns for mobility or adopting the state's concerns over security and sovereignty. Analysing these border negotiations and the relations between citizens and the state, articulated in people's expectations and claims, can provide us with a better understanding of how people participate in the making of borders and contribute to the stability and malleability of political orders.
\end{abstract}

Keywords: border; mobility; security; Russia; Estonia

\section{Introduction}

The towns of Narva and Ivangorod lie opposite each other on the Narova River, which marks the border between Estonia and Russia and the external border of the European Union. Despite being often defined as belonging to two opposing civilizational projects - the West and the East, Europe and Russia - symbolised by the architecture of their historic fortresses, throughout most of their history these two towns have been intimately connected. During the Soviet past, when the area was a major industrial 
centre at the Soviet Union's western fringe, Narva and Ivangorod formed an integrated social and economic space: friendships and kin ties stretched from one town to the other; people went across the bridge to work in one of the large factories on the other side; they engaged in shared leisure activities like singing in a choir, sports activities and going to the cinema and buried their loved ones on a common cemetery. When Estonia declared its independence in 1991 and successively installed border guards and material fortifications along the border, the dense social and economic networks between the towns became more difficult to sustain, and the once integrated borderland turned into a site of divisions and nationalisation. 'Nas razrezali po-zhivomu', a Russian phrase meaning 'we were forced to break off our relations', or literally 'we were cut up alive’ was used repeatedly by my informants to characterise the division of Narva and Ivangorod when I conducted fieldwork on both sides of the border between August 2011 and February 2012. In the eyes of many borderlanders, most of them Russianspeakers who had moved to the borderland during the Soviet past the border had cut through their lives; it was experienced as a forced and violent intrusion of the state into their everyday spaces. Even 20 years after the instalment of the first border guards many people remembered how they had left houses and gardens behind, the difficulties involved in rearranging family relations and workplace arrangements and the general shaking of what was considered 'normality' under Soviet rule.

The fall of the Iron Curtain and the break-up of the Soviet Union as well as two rounds of Eastern enlargement of the European Union in 2004 and 2007 have radically altered the borders of the continent. 'Rebordering Europe' - 'the bureaucratic, legal, and police practices aimed at establishing a tight perimeter around the European Union, while opening up the internal EU borders' (Follis 2012, 12) not only altered the geopolitical map of Europe but also radically transformed the lives of those living 
alongside the newly created divide. This article uses the example of the divided border towns of Narva and Ivangorod to provide a grounded examination of these processes of rebordering Europe after the break-up of the Soviet Union. How is this border lived and interpreted? How can we conceptualise citizens' negotiations of borders and state authority in the borderland? In the face of the increasing bureaucratisation of the border, is the state merely experienced as a negative and disruptive force in the borderland - as reflected in the Russian phrase 'nas razrezali po-zhivomu' - or do we have to assume a more complex relationship between citizens and the state? And what do local perceptions of the border tell us about the tensions at post-Soviet borders more generally? While a number of studies have analysed shifting symbolic geographies and identity constructions in Europe’s East (for example, Zhurzhenko 2010, Kaschuba and Tsympylma 2007, Assmuth 2003), there is relatively little research which explicitly addresses experiences and negotiations of physical borders as 'sites of mobility and enclosure' in the East (Cunningham and Heyman 2004, see however Jansen 2009, Follis 2012, and a number of studies on petty trade and smuggling, Bruns and Miggelbrink 2012a). Based on ethnographic fieldwork and 58 interviews with different ethnic groups living in the borderland ${ }^{1}$, the article seeks to contribute to this scholarship by analysing the multiple responses that the border evokes locally and drawing particular attention to citizens' engagement with state authority. Drawing on recent scholarship in the field of border studies, I make a case for a bottom-up approach to border-making projects that takes into account the differentiated incorporations of statecraft into people's understanding of their bordered lives. State power is always present at the edges of states. Through material border fortifications and controls and the symbolic marking of state territory, citizens have direct and intimate encounters with the state. Due to this presence of the state in everyday life, borderlanders have more knowledge than the 
average citizen about the stakes of statehood and its actual conditions. ${ }^{2}$ Rather than focusing on state structures and the geopolitical narratives that actors of statecraft circulate, the article studies the state as it is interpreted in everyday narratives on the border and foregrounds multiple ways in which it can become a subjective reference point. This approach is useful for the following reasons: Analysing people’s negotiations of the border and sentiments towards the state can provide us insights into how borders are actually perceived on the ground and thus give us a better understanding of their stability and malleability. Furthermore, such an approach can be particularly important for understanding border dynamics in the post-Soviet region where, as this article shows, the border forms a site of particular tensions between security concerns on one hand and claims for greater border mobility and flows on the other.

Empirically, the article compares the narratives of two ethnic groups, Russianspeakers, who constituted the majority of the population on both sides of the RussianEstonian border, and a small group of ethnic Estonians living in Narva, Estonia. The Russian-speakers had moved to the borderland during the Soviet period (1944-1991) to work at the large industrial enterprises that were built after World War II by the regime and were part of a larger influx of settlers from Russia and other Soviet Republics to Soviet-ruled Estonia. The ethnic Estonians on the other hand traced their roots to the time before the war and the first Soviet annexation of Estonia in 1940; many of them experienced repressions under Soviet rule and regarded themselves as victims of the regime. Based on these divergent historical experiences the border appears to them in different forms and is invested with different meanings. In their stories of their border lives, people usually do not question the integrity of the state but drawing on their intimate encounters with statehood they interpret the border in different ways and 
articulate their expectations of how the state should be. The main question for them is not if there is a border but how is the border - whether it runs counter to or corresponds with personal, local or national needs of security, mobility and economic well-being.

The article is structured as follows: firstly, I introduce the conceptual background of the study and the wider political context in which it is situated. Subsequently, I present two narrative frames for engaging with the border foregrounding mobility and cross-border spatialities on one hand, and sovereignty and security on the other - and discuss how the state becomes an object of different emotional engagements and claims-making in these two narratives. Finally, I draw some conclusions about the relations between states and citizens in processes of bordermaking and situate the results within the broader context of post-Soviet borders.

\section{Borders between everyday life and the state}

In a recent article on the Kyrgyzstan-Uzbekistan border, Madeleine Reeves argued for a differentiated analysis of borders and experiences of the 'state' in borderlands, pointing out that we should 'think about the "state" not just as a terrifying externality and its territorial "integrity” an abstraction ripe for deconstruction but also as the locus of intense emotional investment, as a site of enactment or performance, as the source of legitimation, and as an object of hope' (Reeves 2011, 918). Reeves’ article and similar attempts to capture the practical and affective relations between the state and citizens by other scholars (cf. Obeid 2010, Berezin 2003, 2002) alert us to the role of the state - as it is invested with meanings and emotions and becomes an object of expectations - in vernacular experiences of border drawing.

Border studies which has emerged as a new research field over the past three decades have tended to focus either on the making of borders from a statist perspective 
or, using a 'localist' lens, on cross-border flows, alternative spaces, identities and bordering activities which can contest the orders of the state (cf. Alvarez 1995, Donnan and Wilson 1999, Wilson and Donnan 2012). Many studies have traditionally foregrounded on the role of states in the making of borders. They have analysed the symbolic projects of making borders; drawing among others' on Agnew's critique of the ‘territorial trap’ (Agnew 1994), they have looked at the discursive and narrative rendering of state territory by political and cultural elites and aimed at critically deconstructing statecraft. In addition to this, works in historical sociology have provided detailed analyses of processes of state-making, the emergence of (incomplete) territorial sovereignty and attempts at regulating and restricting mobility (O’Dowd 2010, Torpey 2000, Evans et al. 1985). Aiming to 'bringing the state back in’ the social sciences, they have looked at the state as an actor and institutional reality and have contributed to historicising the state by analysing the different forms, unevenness and incompleteness of state-making processes. It has however become increasingly clear that seeing borders exclusively through a statist lens (whether through geopolitical imaginations and narratives or concrete practices and institutional realities) provides only a limited understanding of how borders work and the meanings that inscribed in them (Rumford 2011). Studies have emphasised that borders are constituted by activities at multiple scales, and a diverse range of actors can be involved in making, remaking and contesting them (Johnson and Jones 2014, Rumford 2008, 2011, Rajaram and GrundyWarr 2007, Kaiser and Nikiforova 2006, Balibar 2002) and have in particular called for a consideration of the perceptions and practices of ordinary people in the study of borders (what Chris Rumford has called 'borderwork', 2008). Despite some differences in their conceptual focus and degree of generalisation, these works share the concern for the vernacular with earlier approaches to the study of borders which focused on border 
culture and identities through fieldwork research in particular local settings (for a discussion cf. Donnan and Wilson 1999, Alvarez 1995). Following Reeves’ call, the article seeks to use this localist perspective as a vantage point to analyse the relations between citizens and states in borderlands. In contrast to statist accounts, such an approach does not take the state's narrative about itself for granted but uses the everyday life as a vantage point to understand how it is interpreted and imagined in the borderland. How do people encounter the state in the borderland? Is the order of the state perceived as something malleable and contested or is it non-negotiable? What subjective investments do they make in the state and what expectations do they articulate $?^{3}$ Looking more closely at the productive relations of citizens to state power and the diverse ways in which the state becomes an object of emotional engagements, complaints and claims-making, we can better understand how people participate in the making of borders and territory as well as the tensions that we currently encounter in these processes. In foregrounding people's understandings of the manifestations of the state, this approach also goes beyond many localist studies that, focusing on crossborder spatialities, have conceived of the practices of citizens in the borderland as independent or in opposition to the one of the state (cf. Kinvall and Nesbitt-Larking 2013, Bruns and Miggelbrink 2012b, Rajaram and Grundy-Warr 2007, Edkins and PinFat 2005). Methodologically I use an ethnographic approach to study how borders are experienced and produced by borderlanders, keeping as John Borneman has put it, the 'method and theory sensitive to the historical exactness and density of human life' (Borneman 1998, 189).

\section{Remaking the Russian-Estonian Border}

Over the past two and a half decades the Russian-Estonian border has been transformed 
into an increasingly fortified and bureaucratic border regime. Between the border towns of Narva and Ivangorod the area of border control has been extended from a simple barrier to a large fenced zone equipped with modern surveillance technology, customs control and separate entries for cars and pedestrians. The border crossing has become more bureaucratic; the older and more easily manageable system of document controls through a propusk system (a system of local permits) was replaced by a far more cumbersome visa regime similar to the one other EU member states have with Russia. Customs relations have limited the range and amount of products one can carry across the border, and smuggling has been actively fought (cf. Golunov 2013, Viktorova 2006, Ehin and Berg 2004). This hardening border regime at the EU external frontier is embedded within the larger geopolitical dynamics and polarised imaginations of political space between Russia and Estonia since the dissolution of the Cold War order (Berg and Ehin 2009; Kuus 2004; Smith et al. 1998). In Estonia, redrawing the border to Russia has been one of the key aims since the restoration of independence in 1991. It has been expressed in a number of political decisions, first and foremost, Estonia's geopolitical orientation towards the West (the joining of NATO and EU), the regulation of movement to Estonia with the adoption of a visa system and the exclusionary citizenship policies that were directed against the Russification during the Soviet period and denied those people who moved to Estonia during the Soviet period automatic citizenship status. The protection of the nation and territory, key issues on the political agenda in the post-independence years, remain highly emotionally charged till today.

Russia on the other hand has played an ambiguous role in its relations to Estonia and other neighbouring states and has to varying degrees tried to restore its sphere of influence on those former Soviet republics that have like Estonia tried to orient themselves westwards. The issuing of passports to Russian minorities, the launching of 
pro-Russian media outlets, economic pressures and energy politics as well the support of separatist movements like for example in Moldova/ Transnistria and more recently the Ukraine crisis are only some mechanisms through which Russia has tried to exert geopolitical influence (cf. Bobick 2014 on Moldova/Transnistria and Ukraine, Diener and Hagen 2010 on Kaliningrad). From Russia’s perspective the former Soviet territories are often seen through the "idiom of betrayal” (Yurchak 2014) caused by the former Republics and the West. According to this view, the disintegration of the Soviet Union caused a loss of territory and status, and together with the disenfranchement of Russian citizens living in the near-abroad and the EU and NATO enlargements served to humiliate the Russian nation. Russia’s neoimperial project of establishing a new Eurasian order is part of an active contestation of what it sees as an extension of a Western sphere of influence. Despite periods of relative normalisation in the relations between Russia and Estonia, particularly in the mid-2000s, geopolitical tensions have regularly re-emerged; among others, in a lengthy debate over the border treaty, which, after more than a decade of negotiations, was signed in February 2014 but still awaits ratification; in the 2007 Bronze Soldier crisis, the conflict over the relocation of a Soviet-era WWII monument and subsequent cyber attacks on Estonia, as well as the detention of an Estonian intelligence official investigating smuggling activities at the border in September 2014, whom Russia accuses to be a 'spy'.

It is in this larger geopolitical context that this article inserts the borderland populations and their receptions and negotiations of the border which are often overlooked or are (like the Russian-speaking minority in Estonia and Ukraine) primarily seen as passive objects of mobilisation, a group manipulated by Russian propaganda and potentially a fifth column in the post-Soviet states (cf. Lehti et al 2008, Bobick 2014). Looking at how these people deal with the border and the presence of the state in 
the borderland provides us with a more grounded picture of bordering dynamics in which different border imaginaries are rooted in different historical memories and current positionalities in the borderland.

\section{Disruption of Past Cross-Border Spaces: Narratives of (Im)Mobility in the Borderland}

During my fieldwork stay in the border towns of Narva and Ivangorod, the story most often recounted to me was that of a once integrated borderland where it did not actually matter on which side one lived and of a flourishing industrial region, nurtured by Soviet money and workforce coming from different parts of the Union. This was first and foremost the story of the Russian-speaking population, many of them working class people who had spent large parts of their lives working in the borderland's industrial estates and who constituted the majority of the local inhabitants.

Earlier we used to have one town, Narva and Ivangorod, that means there was a
common transport system, the buses went from Narva to Ivangorod, there was no
division, two towns like one. (...) Of course, now the picture is totally different.
You cannot just cross over, you have to have a visa. And there are problems with
work. (Interview with Aleksandr, cross-border worker living in Narva, b.1967, 18.11.2011)

The situation in the country in relation to the border? I can clearly say that we see this all absolutely negatively. Earlier people went easily over the border - they came to us, we went to them. Now there are these obstacles. To visit your son you have to line up in these queues. Sons, children and grandchildren live there. Family ties (rodstvennye sviazi) were disrupted and you stand there in these crazy queues that nobody wants to solve. (Interview with Viktoriia, a pensioner living in Ivangorod, b. 1958, 16.12.2011)

In most of the everyday talk, the border between Narva and Ivangorod was associated with crossings and travels that had become - due to the introduction of border controls and visa regimes as well as the long waiting lines at the border - increasingly difficult. 
As the confines of the state scale were 'dissonant with borderlanders' other, and often more powerful, conceptions of spatial reality’ (van Schendel 2005, 377) enclosure was experienced like in other places of border enforcement (for example, Megoran 2006, Navaro-Yashin 2003) as a violent intrusion into people's lives that disrupted social and economic cross-border relations. Memories of past mobilities and flows - between Narva and Ivangorod and the Estonian and Russian Soviet republics, the ESSR and the RSFSR - played an important role in this narrative of '(im)mobility'. Mobility was not unregulated during Soviet times: the system of compulsory registration (propiska) restricted movement, particularly the entry to big cities; recent graduates had to take up obligatory placements, and the lack of a flexible housing market further limited opportunities to move elsewhere (on mobility and migration in the USSR, cf. Heleniak 2008, White 2007, Buckley 1995). However, as I was told regularly in interviews, the administrative boundaries of the Soviet republics per se did not pose any restrictions on mobility, and people travelled, obtained work, visited friends across them. In the borderland border-crossing activities were essential constituents of personal life, urban and economic development (Pfoser 2014a); and also in the present these cross-border networks possessed a higher, more immediate relevance than the territory of the two states.

At the personal level there were however great differences in the intensities of experiencing the border as an obstacle. The differentiated permeability of borders has been noted as one of their key characteristics (Balibar 2002). Balibar illustrates this schematically, writing that

For a rich person from a rich country... the border has become an embarkation formality, a point of symbolic acknowledgement of his social status, to be passed at a jog-trot. For a poor person from a poor country, however, the border tends to be something quite different: not only is it an obstacle which is very difficult to 
surmount, but it is a place he runs up against repeatedly, passing and repassing through it as and when he is expelled or allowed to join his family, so that it becomes, in the end, a place where he resides (Balibar 2002, 83).

While this differentiated permeability was clearly observable on the micro-level in the Russian-Estonian borderland, in comparison with other sites of the EU external border where scholars have diagnosed structural asymmetries between those inside and outside the European Union (for example, Jansen 2009 on Bosnia-Herzegovina and Serbia, Follis 2012 on the Polish-Ukrainian border, Assmuth 2013 on rural areas at the RussianEstonian border), narratives of (im)mobility between Narva and Ivangorod were not so much structured by geographical location than by citizenship status and opportunity structures for obtaining a visa as well as their cross-border contacts and obligations (for example, those who had relatives and graves to look after on the other side). According to the citizenship legislation adopted in independent Estonia, the Russianspeaking minority could not automatically obtain Estonian citizenship but had to undergo naturalisation first and pass a test on Estonian language and constitution. Over $40 \%$ of Narva’s Russian-speaking inhabitants had therefore opted for a Russian passport or remained stateless. These differing citizenship statuses on the Estonian side of the border significantly structured people's mobility and created a complex set of bordercrossing abilities.

One person who experienced the border particularly intensely was Iuliia, a retired factory worker in her mid-fifties living in Ivangorod, who lived on her own in a 60s tower block and continued to live a cross-border family life. 'The Berlin wall did not disappear, it was moved here between Narva and Ivangorod' was the first thing she told me. It indicated how intensely the border mattered for her:

I was born in Narva, but because it was difficult under Soviet rule to receive a flat where you lived, I received one here [in Ivangorod]. We were working together. 
Earlier this was one state. That's why a part of my family is in this country and one part in the other. I have a husband whom you won't see there because he comes to me with a visa and needs to go through all kinds of difficulties to get it. (...) Earlier we used to come together for celebrations and sat together around a big table, for birthdays. Now we don't celebrate birthdays anymore. We stopped this. What sense does it make if I can't invite my relatives and not everybody can come here? This means we are totally split up. (Interview with Iuliia, b. 1956, 13.12.2011)

Iuliia seemed angry and exhausted in the interview; she had planned to move together with her second husband but before they managed to get a flat from the municipality, Estonia declared its independence. Her family story reflected all the difficulties of organising one’s family life across a hardening border. In the first years after Estonian independence, her family had benefitted from the simplified border crossing regime for locals which mitigated the local effects of the bordering processes. Since the abolishment of the local border-crossing permits in 2000, her husband and other relatives - all of them were Estonian citizens - had to undergo complicated bureaucratic procedures for obtaining a visa. Although visits were not impossible, sustaining connections required increasingly more work, time and money. In her narrative, Iuliia contrasted the memories of family celebrations in the past to a present shaped by regulations and complained about the intrusion of the state into her private life:

It is insulting. This is my lawful husband, why should some power decide when I should sleep with him. When I will be old I will write my memoirs 'in bed with the prime minister'. Mr Putin and Mr Ansip decided when I should sleep with my husband. This makes me very angry. (Interview with Iuliia, b. 1956, 13.12.2011) Experiences of a hardening border were not only limited to the organisation of life on the local level. Particularly those who moved to Narva during the Soviet period to find work in one of the large factories often complained about the impediments to their mobility over larger distances. People who had kinship networks stretching further 
across the border said that particularly in the first years of the division they had felt 'stranded' and isolated on the other side of the border.

Such negative depictions and characterisation of the borderlanders as victims should not obscure how many borderlanders adapted more pragmatically to the geopolitical changes or successfully negotiated the border by using it as a resource. The different national trajectories and above all the different price regimes had created differentiated structures of opportunities for people (on growing asymmetries in the borderland and their social consequences, cf. Assmuth 2013). Most people in the borderland had excellent knowledge about the changing regulations for crossing and knew how to take advantage of them, reflected in stories about smuggling goods to the other side, questioning the authority of the border guards or crossing over with somebody else's document. Natal'ia, who worked as a tradeswoman on the local market in Ivangorod, made clear that despite the difficult division of the borderland the border had offered her opportunities for making a living by engaging in grey trade:

I think that in the vicinity of a border, people can never die of hunger. You can always earn money. You don't have to smuggle, I mean, no immoral goods like weapons or drugs. I have always said that I shall use all possible means apart from weapons, drugs, robbery, murder and prostitution [laughs]. So far, I have never passed the customs office empty-handed. Anything else would be an empty run. (Interview with Natal'ia, b. 1954, 29.11.2011)

These activities showed playful ways of dealing with the border and stressed the ability to manoeuvre and 'work' it to one's benefit. Like other respondents, Natal'ia however stated that smuggling and grey trade had become more difficult over time and the relative ease of working the border in the 'tumultuous 90s' (likhie devianostie) was gone (for an account of the changes, cf. Golunov 2013, 109-121). Petty trade and smallscale contraband, mostly fuel, alcohol and cigarettes that people affixed to their bodies in the hope that they would not get body-checked by the guards, were the most common 
forms of making use of the border. Observing activities around the border and listening to stories of smuggling, often involving a sense of joy about outwitting the state authorities, it was clear that many people continued to use cross-border trade as a source of income despite the increasing organisational work, time and risk involved in this activity. The border that in the 1990s had still appeared for some as a 'game' had become a physical reality; it was linked to a growing system of control that made it more difficult to use it. It was in this context of the hardening border regime that people articulated their concerns over mobility regulation and the role of the state.

\section{Defending the Border: Sovereignty and Security in the Borderland}

Borders are an expression of the territorial consolidation of states and markers of sovereignty; particularly in post-Soviet states the issues of state sovereignty and the protection of territory have been highly politically charged and serves as a reference point in political debates. Geopolitical arguments for a hard border were not only employed by politicians and cultural elites but also used by a number of Estonian respondents in the borderlands, who associated themselves closely with the Estonian nation and the independence movement during the perestroika. Together with a small number of Russians who had lived in Estonia before its annexation to the Soviet Union and who were as an old minority granted automatic citizenship in Estonia, they formed a distinct group within the borderland. Some of them met regularly at community events and gatherings to sing and dance folk dances, to look after graves and monuments and celebrate national holidays. The border for them was associated with sovereignty and security and they defended it in the light of what they considered as 'persistent threats' emanating from Russia. In contrast to globalised fears of terrorism, immigration and diseases that prevail in the literature on borders, their security concerns were rooted in 
memories of the Soviet past and were usually of diffuse character, merging cultural insecurities (Russia as 'an unpredictable neighbour', disorder, lack of democracy) with fears over an eventual military intervention.

These concerns were particularly pronounced in Sofia's narrative, an ethnic Estonian in her mid-60s whose relatives used to live in Narva before the Soviet annexation and who despite the destruction of the town and the difficulties of the early post-war years had moved back to the borderland immediately after WWII. Sofia narrated her life-story and the story of her family, as part of a larger story of debordering and rebordering Estonia. She foregrounded the destruction of the town during WWII, the repressions and disadvantages of the predominantly Estonian pre-war population including her own family and the influx of migrants from Russia and other Soviet Republics who were culturally and linguistically different as part of the political project of threatening Estonian culture and identity by making it Russian. Against this background Sofia experienced the border drawing in the early 1990s very emotionally and saw it as a necessary step towards liberation and regaining national sovereignty after the Russian occupation.

I remember the day when the last tanks left Estonia. I was on the street and stood, where now you have the customs facilities. I was crying, the tears were just falling out of my eyes, not because I was sorry that they are leaving. I was happy. Yes, I don't want the border to be open. Estonia is very small in comparison with other states in the world and then you still have to bring many things in an order here. Russia is such a huge thing (bolshaia makhina). I think that there you have even more of this disorder. (Interview with Sofia, b.1946, 26.10.2011)

Remembered the symbolic day when the last Russian troops left Estonia, Sofia put the establishment of the border - and the need to keep it closed - in the context of the Russian military presence in Estonia and connected it to a diffuse threat which persists until today. ${ }^{4}$ While she saw rebordering of Estonia as a necessary measure against 
Russia’s domination and negative influence on Estonia, she continued to perceive a threat coming from the other side of the border. Estonia’s geopolitical location has prompted many comments and reflections among politicians and intellectuals, and with 140 million inhabitants in the Russian Federation in comparison to 1.3 million in Estonia and less than a million Estonian-speakers, Estonia's status as being 'small and therefore vulnerable' is a central motif in the discussion about national territorial sovereignty and about Estonia’s integration into EU and NATO (Lauristin 1997). Also Sofia evoked images of a small state which was confronted with Russia's power and 'disorder' and used it to make an argument against those who want the border to be open. Russia's lack of democracy, grey trade ('dirty trade') and drug smuggling over the border were the central themes in the construction of Russia as an 'unpredictable' and ‘scary’ neighbour.

Studies have raised awareness about the role of security in Estonian society and have revealed the diffusion of the security discourse through which citizenship and culture have become objects of securitisation. Gregory Feldman, for example, has demonstrated how the Russian-speaking minority has been constructed as a cultural threat in Estonia (Feldman 2005) both by the national elite and by European actors. Merje Kuus $(2007,2004)$ has documented a general shift in the security rhetoric from military threat to cultural issues in Estonia and Eastern Europe. She writes that ...security claims are increasingly based on more diffuse cultural categories, such as cultural spheres, frontiers, and homelands rather than on the territories of states. Geopolitics is decoupled from state territoriality and transferred into the realms of cultural difference and moral values (Kuus 2007, 118).

According to her, it is particularly the malleability of security discourse which has contributed to its continuing relevance in Eastern European states even after they joined the EU and NATO. This is certainly a valid argument and also Estonians in the 
borderland often used diffuse cultural qualities to characterise 'a Russian threat' to Estonians, sometimes moulding together Russia and Russian-speakers living locally in Estonia. At the same time, state territoriality remained of crucial importance to them. In several of my interviews and encounters during my fieldwork, Russia’s aggressiveness and the possibility of military violence emanating from Russia were raised and Russia was characterised as potentially dangerous, 'greedy' and not willing to give in. This became particularly pronounced during a dinner with a middle-aged Estonian-Jewish family, where we came to speak about Narva's recent history and what they saw as the persisting loyalty of the local Russian-speakers to Russia (fieldwork notes from 22.09.2011). The couple recalled with horror the early 1990s when people openly showed anti-Estonian sentiments and were expecting Russian tanks to come to the town to defend them and their rights. Even now, my host Mikhail said, they could never be sure if Russian tanks would enter Estonian territory. The fact that Narva was populated by Russian-speakers, who would in his eyes even today support such an intervention, increased his feeling of insecurity. In his fear of Russian tanks different memory layers came together - the fear of a Soviet intervention during the restoration of Estonian independence as well as older memories of repression under Soviet rule, experienced by his family and his own experiences of being persecuted and intimidated by the KGB. A Russian-speaking Jew and son of an 'enemy of the people', Mikhail had organised cultural gatherings for young people and had been under surveillance for several years. Several of his and his wife's friends and family members had been deported to the Gulag. 'How can we forget?’ Mikhail asked rhetorically. These memories of past violence were of continuing relevance for him and other Estonians that I spoke to. They also resonated in Sofia's narrative. My question about the recent border formation had brought her back in time to the repressions and insecurities 
experienced during Stalinism, of having to whisper in the evenings in fear that somebody might listen at the window, fearing they could become like many other conationals victims of repressions. Having remembered these insecurities, Sofia brought her thoughts back to the border:

...that's why I don't want to open the border; (it is) too early. I don't say that this should never happen but I think in the first thirty years it is early. (Interview with Sofia, b.1946, 26.10.2011)

Memories of suffering and displacement continue to haunt Estonians living in the borderland. Even before the Ukraine crisis and the Russian annexation of Crimea in March 2014, the image of 'Russian tanks' caused anxiety for some of my Estonian interlocutors. These memories can explain why even though at the time of my fieldwork the likelihood of a Russian military invention seemed small and the Estonian public discourse had refocused on predominantly cultural insecurities after it joined the NATO and the EU (cf. Kuus 2007), the fear of Russia’s continuing imperial desires was pronounced in several encounters. Based on memories of national and personal insecurity, the security narrative normalised and defended the border regime and the integrity of the state territory. Adopting geopolitical discourses it constructed Russia as a threat, while at the same time constructing the border as a remedy against it.

\section{Citizenship Claims and Visions of the State: the Right to Security, Mobility and Care}

Narratives of security and (im)mobility based on divergent historical memories were closely tied to different ways of relating to state authority and ideas about the state. Negotiating the border and making sense of their bordered lives, people expressed different sentiments, expectations and claims towards the state. Like in Sahlins' seminal study on the making of national boundaries between France and Spain (Sahlins 1989), 
people used the border as a resource to articulate personal concerns and pursue their own interests.

In the narrative foregrounding security, the state, the nation and personal identity were closely associated expressing an imagination of what Berezin has called the 'secure state', a territorially bounded (nation-) state that 'channels emotional energy within the polity’ (2002, 39) and stirs confidence and loyalty among its members. State territory was emotionally charged and became a site of comfort and security, which was contrasted to feelings of insecurity in relation to the Russian state, expressed in terms of a lack of protection experienced in Russia or a more general national threat emanating from Russia. In comparison to the positive emotions that Estonians invested in their state, discussions of (im)mobility among Russian-speakers often operated with an implicit or explicit opposition of the state and the people. Russian-speakers living on both sides of the border, who felt excluded from political decisions and frustrated about how the tense geopolitical relations affected local life, portrayed the state as a violent intruder, who disturbed their previous social and economic arrangements. This applied to the perception of both the Estonian and Russian states: while the complaints addressed different problems and were often directed to one's own government, people usually held both states responsible for the difficulties in crossing the border. In the light of past mobilities, present socioeconomic insecurities and increasing mobility in other parts of Europe, they adopted a local perspective privileging the local scale and interests over the bounded territory of the nation-state and defended their right to mobility and smuggling. Seeing their critique of the border enforcement merely as an act of opposition however only captures half of the picture. Russian-speakers articulating concerns over mobility also gave voice to their expectations vis-à-vis the state and made significant emotional investments in the state. While the hardening of 
the border was regarded as a sign of 'too much state presence' in the borderland, complaints were made over its absence in other fields, against what they saw as the lack of state care and social benefits to ease social and economic difficulties experienced in the border region. Iuliia, a pensioner from Ivangorod, whose interview was quoted earlier, argued:

Of course, every people has the right of self-determination. This is how it was written in the Soviet constitution. If the Estonians want to live separately, of course, they should have the right to do so but the border should not violate the rights of the people who live alongside it. They need help to adapt to this life. Once the border appears you need to give them some benefits, you need to help them, so that they don’t perceive the state in a negative way. (Interview with Iuliia, b. 1956, 13.12.2011)

Ultimately, it was not less state and the dissolution of the border that Iuliia desired but a state that cared and provided its citizens with benefits to counteract the disadvantages of life in a border town. Similar concerns were also raised by local business people like Anton, who worked in Narva and was particularly worried about the local economic consequences of the border drawing.

When the economic crisis started, people lost their jobs and people started to go from Narva to Ivangorod to buy cigarettes. And to go to Ivangorod, there was the problem that you had to stand in a line for half a day to go there. The line of people grew. To solve the problem, they could have increased the salaries and created more working places so that people are not without work. No. They just decided to limit the amount of what you can take [across the border] and introduced more controls and punishments. That's how they solved it. The people don't live well? You have to limit them, and they will adjust somehow. A state should love its people and not treat it in this way (Interview with Anton, b.1965, 25.10.2011)

Anton's story characterised cross-border trade as a way of coping with financial difficulties in the face of the economic crisis and risen prices. Limitations on the quantity and type of imported goods that can be brought from Ivangorod were 
interpreted as a sign of the state's 'hatred'. Particularly in the face of the economic decline that the borderland had experienced in the course of the privatisation of the industries Anton claimed that it should not simply be the state that benefits from the border; borderlanders should also be able to take local advantage. Expressing their frustration and disappointments with the practices of border control, he and other people articulated inherited ideas of how a state should be, namely a state that does not restrict people, but instead provides support and care. Concerns about the right to mobility were thus not only articulated in the context of personal cross-border relations but also economically as a right to make use of the border. Smuggling and grey trade were described by many as a legitimate income and coping strategy in times of financial difficulties, framing them as albeit 'illegal' 'licit' (Abraham and van Schendel 2005, 4). These articulations occur in a context where the state in the eyes of the borderlanders cannot provide sufficient care for the people. Particularly in the context of unemployment and the financial and economic crisis, people saw cross-border trade as a necessary and rightful means of dealing with the economic insecurities.

\section{Conclusion}

The relations between Russia and its neighbours have been characterised by geopolitical tensions since well before the recent Ukraine crisis and Russia's annexation of the Crimea. Since the end of the Cold War order, the post-Soviet borders have been shaped by divergent political projects and imaginations of desirable political and spatial orders, articulated in nation-building projects, the integration of former Soviet Republics into Western alliances and Russia’s attempts at re-establishing its geopolitical influence in the region. As sites of political struggles, contestation and renegotiation, borders are therefore particularly well-suited for undertaking an analysis of these tensions. This 
article suggests that a deeper understanding of border dynamics in the post-Soviet region and beyond requires an analysis of how people come to interpret the manifestations of the state. Analysing how borderlanders narrate their lives and relate to state authority give us insights into the stability and malleability of political orders.

Focusing on the local dynamics at the Russian-Estonian border the article showed how concerns over security stand in contrast to the wish to keep borders open and fluid to maintain social, cultural and emotional ties across the border. Depending on different positionalities and memories of the past, ethnic Estonian and Russian-speaking populations engaged in different relations with the state - adopting the state's concern over security and sovereignty on one hand, and privileging local concerns over state interest on the other. Rather than imagining a strong state and a sharp divide between Russia and Estonia, Russian-speakers mobilised an imagination of the state in the service of local concerns, facilitating movement and helping borderlanders to adapt to new border realities. With concerns over security occurring alongside with resistance to state boundaries, there are similarities to the US-Mexican border where a security discourse fuelled by fears over illegal immigration and drug trafficking has taken hold among the white American population that stands in opposition to Mexicans' laments about the violence of the hardened division.

To evaluate these and other negotiations of borders and state authority, it is however important to take into account the specific socio-political context in which they are embedded. We have to consider Russian-speakers claims to mobility and investments in a fluid post-Soviet order based on past ties, economic advantages of cross-border flows as well as cultural affiliations to Russia in the context of asymmetric relations between Russia and its neighbours. Particularly in the light of the Ukraine crisis, the prioritisation of local spatial orders over concerns of national security can be 
interpreted as an expression of lacking loyalty to the state and an undermining of national stability. Even if not necessarily intended by the Russian-speakers who constitute a diverse group with different political affiliations, these can be politically useful and mobilised in Russia’s attempts to undermine geopolitical stability of the region and Estonia in particular. As Bobick (2014) and Zhurzhenko (2014) pointed out in relation to the separatist movements in Moldova and Ukraine, the articulation of local demands and grievances against the central government can in specific political contexts serve a neoimperialist Russian agenda, trying to shift the boundaries of Europe and Eurasia. In the context of asymmetric power relations, this destabilisation of the political order is also what Estonians worry about when they express their concerns over security and embrace national boundedness. Of course, there are differences between Estonia and Ukraine - Estonia’s membership in the EU and NATO provide international protection, and the higher living standards and social security arrangements make separatist movements a non attractive option for the Russianspeakers living in Estonian Narva, even for the ones who continue to feel a cultural affiliation to Russia. Their wish for mobility and a more fluid spatial order is primarily rooted in concerns to keep social ties up and a way to deal with a difficult economic situation. As internal borders within the EU show, mobility and feelings of security at borders do not necessarily contradict each other. It is an open question whether alternative border imaginaries that accommodate these two concerns can take hold at the Russian-Estonian border, so that mobility and cross-border ties are facilitated without leading to feelings of anxieties among Estonians. What seems certain though is that in the current political situation a desecuritisation of the border is highly unlikely. 


\section{References}

Abraham, Itty, and Willem van Schendel. 2005. "Introduction: The Making of Illicitness.” In Illicit Flows and Criminal Things. States, Borders, and the Other Side of Globalization, edited by Willem van Schendel and Itty Abraham, 1-37. Bloomington: Indiana UP.

Agnew, John. 1994. "The Territorial Trap: The Geographical Assumptions of International Relations Theory.” Review of International Political Economy 1(1): 53-80.

Alvarez, Robert R. Jr. 1995. “The Mexican-US Border: The Making of an Anthropology of Borderlands.” Annual Review of Anthropology 24 (1): 447-470.

Assmuth, Laura. 2003. "Nation Building and Everyday Life in the Borderlands between Estonia, Latvia and Russia.” Focaal 41 (1): 59-70.

Assmuth, Laura. 2013. “Asymmetries of Gender and Generation in a Post-Soviet Borderland.” In Border Encounters. Asymmetry and Proximity at Europe's Frontiers, edited by Bacas, Jutta Lauth and William Kavanagh, 139-164. New York, Oxford: Berghahn.

Balibar, Etienne. 2002. "What is a Border?” Chapter 4 in Politics and the other Scene. London: Verso.

Berezin, Mabel. 2002. “Secure States: Towards a Political Sociology of Emotions.” In Emotions and Sociology, edited by Jack Barbalet, 33-52. London: Basil Blackwell.

Berezin, Mabel. 2003. “Introduction: Territory, Emotion and Identity: Spatial Recalibaration in a New Europe.” In Europe without Borders: Remapping Territory, Citizenship and Identity in a Transnational Age, edited by Mabel Berezin and Martin Schain, 1-32. Baltimore: John Hopkins University Press. Berg, Eiki, and Piret Ehin, eds. 2009. Identity and Foreign Policy. Baltic-Russian Relations and European Integration. Farnham, Burlington: Ashgate.

Bobick, Michael S. 2014. “Separatism redux. Crimea, Transnistria and Eurasia’s de facto states.” Anthropology Today 30 (3): 3-8.

Borneman, John. 1998. “Grenzregime (Border Regime): The Wall and Its Aftermath.” In Border Identities. Nation and State at International Frontiers, edited by Thomas M. Wilson and Hastings Donnan, 162-190. Cambridge: Cambridge University Press. 
Bruns, Bettina and Judith Miggelbrink, eds. 2012a. Subverting Borders. Doing Research on Smuggling and Small-Scale Trade. Wiesbaden: Verlag fuer Sozialwissenschaften.

Bruns, Bettina and Judith Miggelbrink. 2012b. “Introduction.” In Subverting Borders. Doing Research on Smuggling and Small-Scale Trade, edited by Bettina Bruns and Judith Miggelbrink, 11-19. Wiesbaden: Verlag fuer Sozialwissenschaften. Buckley, Cynthia. 1995. “The Myth of Managed Migration: Migration Control and Market in the Soviet Period.” Slavic Review 54 (4): 896-916.

Cunningham, Hilary and Josia McC. Heyman. 2004. "Introduction: Mobilities and Enclosures at Borders.” Identities. Global Studies in Culture and Power 11 (3): 289-302.

Diener, Alexander C. and Joshua Hagen. 2010. “Russia’s Kaliningrad Exclave:

Discontinuity as a Threat to Sovereignty.” In Borderlines and Borderlands: Political Oddities at the Edge of the Nation-State, edited by Alexander C. Diener, and Joshua Hagen, 121-136. Plymoth: Rowman\&Littlefield.

Donnan, Hastings and Thomas M. Wilson. Borders. Frontiers of Identity, Nation and State. Berg: Oxford, 1999.

Edkins, Jenny and Veronique Pin-Fat. 2005. “Through the Wire: Relations of Power and Relations of Violence.” Millenium. Journal of International Studies 34 (1): $1-24$.

Ehin, Piret and Eiki Berg. 2004. "EU Accession, Schengen, and the Estonian-Russian Border Regime.” In The Estonian Foreign Policy Yearbook 2004, edited by Andres Kasekamp, 45-61. Tallinn: Estonian Foreign Policy Institute.

Evans, Peter B., Dietrich Rueschemeyer and Theda Skocpol. 1985. Bringing the State Back In. Cambridge: Cambridge University Press.

Feldman, Gregory. 2005. "Culture, State, and Security in Europe. The case of citizenship and integration policy in Estonia.” American Ethnologist 32 (4): 676694.

Follis, Karolina S. 2012. Building Fortress Europe. The Polish-Ukrainian Frontier. Philadelphia: University of Pennsylvania Press.

Golunov, Serghei. 2013. EU-Russian Border Security. Challenges, (Mis)Perceptions, and Responses. Milton Park: Routledge. 
Heleniak, Timothy. 2008. “An Overview of Migration in the Post-Soviet Space.” In Migration, Homeland, and Belonging in Eurasia, edited by Cynthia J. Buckley, Blair A. Ruble and Erin Trouth Hofmann, 29-67. Washington: Woodrow Wilson Center Press.

Jansen, Stef. 2009. “After the Red Passport: Towards an Anthropology of the Everyday Geopolitics of Entrapment in the EU's 'Immediate Outside'.” Journal of the Royal Anthropological Institute 15 (4): 815-832.

Johnson, Corey and Reece Jones, eds. 2014. Placing the Border in Everyday Life. Ashgate: Farnham.

Kaiser, Robert and Elena Nikiforova. 2006. "Borderland Spaces of Identification and Dis/Location: Multiscalar Narratives and Enactments of Seto Identity and Place in the Estonian-Russian Borderlands.” Ethnic and Racial Studies 29 (5): 928958.

Kaschuba, Wolfgang and Tsypylma Darieva, eds. 2007. Representations on the Margins of Europe. Politics and Identities in the Baltic and South Caucasian States. Frankfurt a.M.: Campus.

Kinnvall, Catarina and Paul Nesbitt-Larking. 2013. “Securitizing Citizenship: (B)ordering Practices and Strategies of Resistance.” Global Society 27 (3): 337359.

Kuus, Merje. 2004. “Those Goody-Goody Estonians': Toward Rethinking Security in the European Union Applicant States'.” Environment and Planning D: Society and Space 22 (2): 191-207.

Kuus, Merje. 2007. Geopolitics Reframed: Security and Identity in Europe's Eastern Enlargement. New York: Palgrave Macmillan.

Lauristin, Marju. 1997. “Contexts of Transition.” In Return to the Western World: Cultural and Political Perspectives on the Estonian Post-Communist Transition, edited by Marju Lauristin, Peeter Vihalemm, Karl Erik Rosengren and Lennart Weibull 25-40. Tartu: Tartu University Press.

Lehti, Marko, Matti Jutila, and Markku Jokisipilä. 2008. “Never-ending Second World War: Public Performances of National Dignity and the Drama of the Bronze Soldier.” Journal of Baltic Studies 39 (4): 393-418. 
Megoran, Nick. 2006. “For Ethnography in Political Geography: Experiencing and Reimagining Ferghana Valley Boundary Closures.” Political Geography 25 (6): 622-640.

Navaro-Yashin, Yael. 2003. “'Life is dead here'. Sensing the political in 'no man's land'.” Anthropological Theory 3 (1): 107-125.

O'Dowd, Liam. 2010. “From a 'borderless world' to a 'world of borders': 'bringing history back in'.” Environment and Planning D: Society and Space 28 (6): 10311050.

Obeid, Michelle. 2010. “Searching for the 'ideal face of the state' in a Lebanese border town.” Journal of the Royal Anthropological Institute 16 (2): 330-346.

Pfoser, Alena. 2014a. "Between Russia and Estonia. Narratives of Place in a New Borderland.” Nationalities Papers 42 (2): 269-285.

Pfoser, Alena. 2014b. Borderland Memories. The Remaking of the Russian-Estonian Frontier. Unpublished $\mathrm{PhD}$ thesis. Loughborough University.

Rajaram, Prem Kumar and Carl Grundy-Warr, eds. 2007. Borderscapes: Hidden Geographies and Politics at Territory’s Edge. Minneapolis: University of Minnesota Press.

Reeves, Madeleine. 2011. "Fixing the Border: on the Affective Life of the State in Southern Kyrgyzstan.” Environment and Planning D: Society and Space 29 (1): 905-923.

Rumford, Chris. 2008. “Introduction: Citizens and Borderwork in Europe.” Space and Polity 12 (1): 1-12.

Rumford, Chris. 2011. “Seeing Like a Border.” Political Geography 30 (2): 67-69.

Sahlins, Peter. Boundaries: The Making of France and Spain in the Pyrenees. Berkeley: University of California Press, 1989.

Smith, Graham, Vivien Law, Andrew Wilson, Annette Bohr and Edward Allworth, eds. 1998. Nation-building in the Post-Soviet Borderlands. The Politics of National Identities. Cambridge: Cambridge UP.

Torpey, John. 1999. The Invention of the Passport. Surveillance, Citizenship and the State. Cambridge: Cambridge University Press.

Van Schendel, Willem. 2005. The Bengal Borderland. Beyond State and Nation in South Asia. London: Anthem Press. 
Viktorova, Jevgenia. 2006. "Conflict Transformation the Estonian Way. The EstonianRussian Border Conflict, European Integration and Diversification of Estonia's Discursive Space.” Paper presented at CEEISA $4^{\text {th }}$ Annual Convention, Tartu, Estonia, 25-27 June 2006.

White, Anne. 2007. "Internal Migration Trends in Soviet and Post-Soviet European Russia.” Europe-Asia Studies 59 (6): 887-911.

Wilson, Thomas M. and Hastings Donnan. 2012. Borders and Border Studies. In: A Companion to Border Studies, edited by Thomas M. Wilson and Hastings Donnan, 1-25. Chichester: Wiley-Blackwell.

Yurchak, Alexei. 2014. "Little green men: Russia, Ukraine, and post-Soviet sovereignty.” Anthropolitea. Accessed 18 November 2014. http://anthropoliteia.net/2014/03/31/little-green-men-russia-ukraine-and-postsoviet-sovereignty/2014

Zhurzhenko, Tatiana. 2010. Borderlands into Bordered Lands: Geopolitics of Identity in Post-Soviet Ukraine. Stuttgart: Ibidem-Verlag.

Zhurzhenko, Tatiana. 2014. From Borderlands to Bloodlands. Eurozine. Accessed 18 November 2014. http://www.eurozine.com/articles/2014-09-19-zhurzhenkoen.html

1 Interviews were conducted with people belonging to different generational cohorts. This article mainly focuses on ethnic differences in interviews with people who came of age before the redrawing of the border. Generational differences are discussed at great length in Pfoser 2014b.

2 I thank one of the anonymous reviewers for pointing this out.

3 I consider the 'state' as an imagined unity in citizens' account of their bordered lives rather than assuming that it is a clearly defined, unified actor.

4 Even after the restoration of independence, Russian troops continued to be based in Estonia and in the face of political controversies regarding Estonia's treatment of the Russianspeaking minority, the troop withdrawal was consciously delayed to augment Russia’s pressure on Estonia. Russian troops finally withdrew from Estonia on 31 August 1994. 